\title{
Foliar anatomy of ten genotypes of the plant Manihot esculenta (Euphorbiaceae)
}

\section{Jaime Marín ${ }^{1,3}$, Edgar Javier Rincón Barón² \& James Montoya-Lerma1}

1. Departamento de Biología, Facultad de Ciencias Naturales y Exactas, Universidad del Valle, Calle 13 No 100-00, Cali, Colombia; james.montoya@correounivalle.edu.co

2. Universidad de Santander, Facultad de Ciencias de la Salud, Grupo de Investigación Agroambiente y SaludMICROBIOTA, calle 70 No 55-210, Campus Universitario Lagos del Cacique, Bucaramanga, Colombia; ed.rincon@mail.udes.edu.co, ejrbaron@gmail.com

3. Corporación Colombiana de Investigación Agropecuaria - AGROSAVIA, Km. 9 vía Espinal, Colombia; jamarin@agrosavia.co

\section{Received 06-VIII-2019. Corrected 24-IV-2020. Accepted 10-VI-2020.}

\begin{abstract}
Introduction: Cassava Manihot esculenta (Crantz) is a perennial shrub native to South America that is an essential source of carbohydrates for more than 600 million people in tropical countries. Objective: The aim of this study was to describe and compare the leaf blade anatomy of ten genotypes of cassava. Methods: The methodology for anatomical descriptions was processed and 30 leaves of each of the varieties were included and sectioned according to paraffin impregnation protocols. Results: The results showed that the leaf blade anatomical structure of all the varieties in general terms show differences. All varieties had monostratified epidermis, leaf mesophyll consisted of a palisade parenchyma in a single layer and multiple layers of spongy parenchyma. Polyphenolic idioblasts were observed immersed in the palisade parenchyma and spongy parenchyma. Between 3-7 xylem ribs with their respective phloem were found in the midrib in almost all varieties. Trichomes were only found in two varieties (NAT31-ECU72) and leaves were all hipostomatic. Conclusions: The results reveal that NAT31 is the material with the most anatomically marked differences (i.e. presence of trichomes, papillary cell, and, on the adaxial face, special provision in the arrangement of stomata and epicuticle wax patterns), characteristics that might be related to pest resistance.
\end{abstract}

Key words: cassava; idioblasts; mesophyll; polyphenols; trichomes.

Marín, J., Rincón, E., \& Montoya-Lerma, J. (2020). Foliar anatomy of ten genotypes of the plant Manihot esculenta (Euphorbiaceae). Revista de Biología Tropical, 68(3), 919-932.

Manihot esculenta Crantz cassava is a perennial Euphorbiaceae shrub which propagates vegetatively and is the only member of the family cultivated as food (Fauquet \& Fargette, 1990). Its worldwide production is estimated at over 280 million tons and as constituting an essential source of carbohydrates for over 600 million people in tropical countries (FAO, 2012). Besides human consumption, cassava is widely used in transformed products and as animal feed. Industrially, it is used as a main ingredient in ethanol and starch production
(FAO, 2012). Nevertheless, its production and yield are limited by biotic (diseases, virus, insects, mites and weeds) and abiotic (soils, climate, etc.) factors. Diseases and pests are among the biotic factors with most impact on the crop (Bellotti, Vargas, Reyes, \& Guerrero, 2002). Although around 200 species of arthropods are associated with the crop, only a few become pests causing economic damage (v.g. the cassava green mite (CGM) Mononychellus tanajoa (Acari: Tetranychidae). This mite has co-evolved with the plant adapting in several 
ways to the latex and cyanogenic compounds produced as a possible defense mechanism by plant (Bellotti et al., 2002). Few studies evaluate the pre-established physical barriers found on the epidermis of Manihot plants (Bellotti \& Arias, 2001; Nukenine, Dixon, Hassan, \& Zalom, 2002; Bellotti, 2008; Mutisya, ElBanhawy, Khamala, \& Kariuki, 2015). For instance, Nukenine, Hassan, and Dixon, 2000, and Nukenine et al., 2002, determined that the type of reticulate nerve and the morphology of the leaf blade are very similar among all genotypes analyzed in their study. Additionally, the anatomy of these genotypes is characterized by possessing few cells of sclerenchyma, xylem and phloem, and numerous thick-walled cells in the parenchyma and sclerenchyma. According to Klamkoeski, Sekrecka, Fonyodi, \& Treder, (2006) fine structural alterations in protoplast coagulation and makes the chloroplasts swell, disorganizing the thylakoids and causing them to acquire a cup-like form. These alterations when are caused by a green mite attack imply a reduction or affectation of $\mathrm{CO}_{2}$ assimilation and transpiration. Likewise, green mite infestation produces modifications in the structure of the stomata and the mesophyll (Klamkowski, Sekrecka, Fonyodi, \& Treder, 2006). El-Sharkawy, Cock, \& Porto, (1989) found changes in the foliar anatomy at the mesophilic level that could modify the diffusion of $\mathrm{CO}_{2}$.

In addition, there are few studies about cassava comparing varieties at anatomical level in order to establish differences and possible relationships with resistance or tolerance characteristics to biotic and/o abiotic stresses (Nukenine et al., 2002; Riis, Bellotti, Bonierbale, \& O'Brien, 2003; Burbano, Carabalí, Montoya-Lerma, \& Bellotti, 2007; Bellotti, 2008; Mutisya et al., 2015). Da Cunha Neto, Martins, Caiafa, \& Martins, (2014) described the anatomy of the leaves of wild species of Manihot and identified important taxonomic characteristics.

In the present study the leaf anatomy of ten genotypes from the Manihot esculenta germplasm bank is described and compared. Hence, this represents the first research to describe the various anatomic (epidermis and the leaf blade) characteristics of these varieties which are basic to understand the plant defenses against its natural pests.

\section{MATERIALS AND METHODS}

This study was carried out in greenhouses at the Universidad del Valle (Univalle), Cali, Colombia $\left(28 \pm 2{ }^{\circ} \mathrm{C}, 70^{\circ} \pm 5\right.$ Relative Humidity) in 2014 , and by scanning electron microscopy at the Escuela de Materiales (Universidad del Valle) and the Botany Laboratory at the Universidad de Antioquia, Medellin, Colombia.

For the analysis, all of the genotypes were set in vitro, multiplied (Univalle Tissue Culture Laboratory) and then planted in sterile soil in $1 \mathrm{~kg}$ plastic pots, and kept in a greenhouse at $30 \pm 2{ }^{\circ} \mathrm{C}$ y $70 \% \pm 5 \%$ RH-relative humidity. Basically, varieties were chosen based on their physiological characteristics associated/verified with tolerance to mites or other cassava pests (Table 1).

Table 2 describes a comparison of the different anatomical characteristics of the foliar lamina of the ten cassava genotypes (SEC = Shape of epidermis cells, $\mathrm{T}=$ Trichome, LSFL = Location of the stomata in the foliar lamina, PTTS $=$ Presence of two types of stomata, RWP $=$ Reticular wax pattern, $\mathrm{CW}=$ Crest waxes, $\mathrm{CH}=$ Crest height, $\mathrm{MD}=$ Midrib diameter, $\mathrm{P}=$ Polyphenols).

Processing of vegetal samples: 30 fragments $1 \mathrm{~cm}$ thickness were taken from the middle of the leaflets of completely developed leaves from each of the ten varieties, for a total 300 fragments studied and fixed in a mixture of formaldehyde, ethanol and acetic acid (FAA) for 24-48 hours at $6{ }^{\circ} \mathrm{C}$. They were cut in smaller fragments, $0.5 \mathrm{~cm}$ wide, dehydrated in a gradual series of alcohols and later passed through two changes of xylene and then placed in Paraplast Plus (McCormick ${ }^{\circledR}$ ) for 12 hours at $55{ }^{\circ} \mathrm{C}$ (Ruzin, 1999). Cross sections, 3-5 $\mu \mathrm{m}$ thick, were obtained using a Leica model rotary microtome-RM $2125^{\circledR}$. These sections were 
TABLE 1

Genotypes selected for evaluating green mite attack that demonstrated tolerance to this and other cassava pests

\begin{tabular}{|c|c|c|c|c|}
\hline Genotype & Mite & White fly & Other plagues & Reference \\
\hline ALT 6 & M. tanajoa & & & CIAT, 2004 \\
\hline ALT12 & M. tanajoa & & & CIAT, 2004 \\
\hline PER415 & - & - & - & - \\
\hline ECU 72 & & Sociales; B. tabaci & & $\begin{array}{l}\text { Bellotti y Arias, 1981; Gómez, 2004; Carabali et al., 2009; } \\
\text { Bohórquez, 2009; Omongo et al., 2012; Parsa et al., } 2015 .\end{array}$ \\
\hline ECU 160 & M. tanajoa & & & Burbano et al., 2007 \\
\hline NAT 31 & & A. socialis & & Vargas et al., 2002 \\
\hline PER 182 & M. tanajoa & & & Boaventura et al., 2012 \\
\hline PER 335 & M. tanajoa & A. socialis & & Bellotti y Arias, 1981; Boaventura et al., 2012 \\
\hline 60444 & & & Erinnyis ello & CIAT, 2004 \\
\hline
\end{tabular}

TABLE 2

Comparison of the anatomic characteristics of the foliar lamina of the ten cassava genotypes

\begin{tabular}{|c|c|c|c|c|c|c|c|c|c|}
\hline Genotypes & FCB & $\mathrm{T}$ & UELF & PDTE & PRC & $\mathrm{CC}$ & $\mathrm{AC}$ & DNP & $\mathrm{P}$ \\
\hline ALT6 & Rectangular & Absence & Hipostomatic & Not turgid & Presence & Presence & Mid & Wide & Presence \\
\hline ALT12 & Rounded & Absence & Hipostomatic & Not turgid & Absence & Absence & Mid & Thin/Narrow & Presence \\
\hline ECU72 & Papilar & Presence & Hipostomatic & Not turgid & Presence & Absence & Low & Thin & Presence \\
\hline ECU160 & Papilar & Absence & Hipostomatic & Not turgid & Presence & Absence & Mid & Thin & Ausence \\
\hline NAT31 & Papilar & Presence & Hipostomatic & Not turgid & Presence & Absence & Mid & Thin & Presence \\
\hline PER182 & Rectangular & Absence & Hipostomatic & Turgid & Presence & Absence & Mid & Thin & Presence \\
\hline PER335 & Papilar & Absence & Hipostomatic & Not turgid & Presence & Absence & High & Wide & Absence \\
\hline PER415 & Papilar & Absence & Hipostomatico & Turgid & Presence & Absence & Low & Wide & Absence \\
\hline 60444 & Papilar & Absence & Hipostomatic & Not turgid & Presence & Absence & Mid & Thin & Absence \\
\hline CMC40 & Papilar & Absence & Hipostomatic & Not turgid & Presence & Absence & Mid & Wide & Absence \\
\hline
\end{tabular}

$\mathrm{SEC}=$ Shape of epidermis cells, $\mathrm{T}=$ Tricome, $\mathrm{USFL}=$ Location of the stoma in the foliar lamina, PTTS $=$ Presence of two types of stoma, $\mathrm{RPW}=$ Recticular pattern of waxes, $\mathrm{WC}=$ Waxes in the crests, $\mathrm{CH}=$ Crest height, $\mathrm{MD}=$ Midrib diameter, $\mathrm{P}=$ Polyphenols.

then stained with Safranin and blue Alcian in order to emphasize lignified and non-lignified walls, respectively. The presence of polyphenolic compounds was also detected with vanilla stain and ferric chloride (Ruzin, 1999). During the anatomic analysis, special attention was given to the characteristics of both epidermis surfaces, like trichomes and papilliform cells as well as the detection of polyphenols in the palisade parenchyma and spongy. The histologic organization of the main rib of the leaf blade was analyzed.

The sections were studied using a Nikon $90 \mathrm{i}$ eclipse ${ }^{\circledR}$ photonic microscope equipped with a differential contrast interference system (DCI). The images were processed by an Image-Pro Analyzer 6.3 Program from Media Cybernetics.

For Scanning Electron Microscope (SEM) observations, ten replicas of leaf segments were taken for each of the varieties studied and fixed in glutaraldehyde in $7.2 \mathrm{pH}$ phosphate buffer for 48 hours. Later, there were dehydrated in 2.2 dimethoxypropane and dried in hexadimethyldilizane (Buravkov, Chernikov, $\&$ Buravkova, 2011). The leaf segments were placed on a conductive carbon double-faced tape and coated with gold in a Denton Vacuum Desk IV ionizer for 3 minutes. The processed samples were observed under a JEOL JSM$6490 \mathrm{LV}$ microscope. The abaxial face of the leaflet was studied paying special attention 
to the arrangement of the stomata, presence of trichomes and stomata, and epicuticular wax patterns.

\section{RESULTS}

The qualitative anatomic characteristics of ten Manihot esculenta Crantz genotypes selected for this study are summarized in Table 2 .

Leaf lamina or Leaf blade: In the transverse sections, the structure of the leaf blade is homogeneous in all varieties, both on the abaxial and the abaxial surface of the leaflets. The adaxial epidermis is mono-stratified under which the palisade parenchyma is located, also, in a single layer, are located (Fig. 1A, 1B, 1G, $1 \mathrm{H}, 1 \mathrm{I})$. Since the leaves of all varieties analyzed are hipostomatic leaf (Fig. 1E, 1L, Fig. 2F, 2J, Fig. 3K, Fig. 4E, 4K, Fig. 5E, 5L), the spongy parenchyma is formed by 2-4 layers of cells that contact the sub-stomatal cavities towards the abaxial surface the leaflet. The epidermis of the ALT6, ALT12 and PER182 varieties is formed by rectangular or rounded cells on both surfaces of the leaflet (Fig. 1A, 1B, 1C, $1 \mathrm{G}, 1 \mathrm{H}, 1 \mathrm{I}$, Fig. 2A, 2B, 2C, respectively). In other varieties analyzed, the adaxial epidermis is also formed by rectangular or rounded cells, but the abaxial epidermis cells papilliform (Fig. $3 \mathrm{~A}, 3 \mathrm{~B}, 3 \mathrm{C}, 3 \mathrm{G}, 3 \mathrm{H}, 3 \mathrm{I})$ and both sides of the leaf have papillary cells (Fig. 4B, 4C, 4G, 4H, Fig. 5A, 5B, 5G, 5H, 5I).

Stomata: All the varieties analyzed are hipostomatic, the stomata are located only on the adaxial surface of the leaflet at the same level of the epidermal cells. The guard cells have a reniform shape. Nevertheless, in the PER182 and PER415 varieties, in addition to the typical, two other stomata were observed. Those superficial or at the same level of the rest of the epidermal cells and the other with turgid occlusive cells arising above the level of the rest epidermal cells (Fig. 2D, 2F, Fig. 5L, Table 2)
Epicuticular waxes: The stomata on the abaxial surface of the leaflet are partially or totally covered by epicuticular waxes forming a discontinuous reticule in almost all the varieties analyzed. However, only in Fig. 1E (ALT6) it is observed that they surround the stomata, though the thickness of the walls of this reticule is variable but being thicker in ALT6 (Fig. 1D, $1 \mathrm{E}, 1 \mathrm{~F})$. This reticule is almost continuous in the PER335 variety (Fig. 5E).

Only the ALT12 variety have between ribs the epicuticular waxes follow the reticulated pattern, but on vascular bundles there is greater deposition and following the orientation of the ribs and presents wax crests running almost parallel to each other and perpendicular alignments to vascular bundles are depositions of epicuticular waxes over smaller ribs (Fig. 1K, 1L, Table 2). The ALT6 variety, the reticulum formed by the epicuticle waxes have only high rounded crests (Fig. 1E, 1F). The ECU72 and PER 415 varieties (Fig. 3E, Fig. 5L, respectively; Table 2) have the lowest crests among all of those analyzed, while PER335 presents the highest epicuticle crests (Fig. 5D, 5E, Table 2).

Midrib: The midrib, with annular or angular collenchyma layers on both surfaces, is similar in all varieties and can be distinguished by the number of the cells layer (Fig. $1 \mathrm{G}, 1 \mathrm{H}$, 1I, Fig. 2D, 2J, 2L, Fig. 3E, 3L, Fig. 4D, 4J, 4L, Fig. 5J). The fundamental parenchyma fills the space between the collenchyma and the vascular system. The vascular bundle of the midrib is formed by a collateral closed vascular bundle with phloem towards the leaf abaxial face leaflet (Fig. 1E, 1F, 1K, Fig. 2D, 2J, 2L, Fig. 3E, 3L, Fig. 4D, 4J, 4L, Fig. 5J). In all varieties, the midrib presents qualitative differences in height and width (Table 2), number of the parenchyma layers between the collenchyma on the abaxial surface and the vascular bundle.

Polyphenols: Polyphenols were mainly detected in idioblasts associated with ground palisade and spongy parenchyma, though 

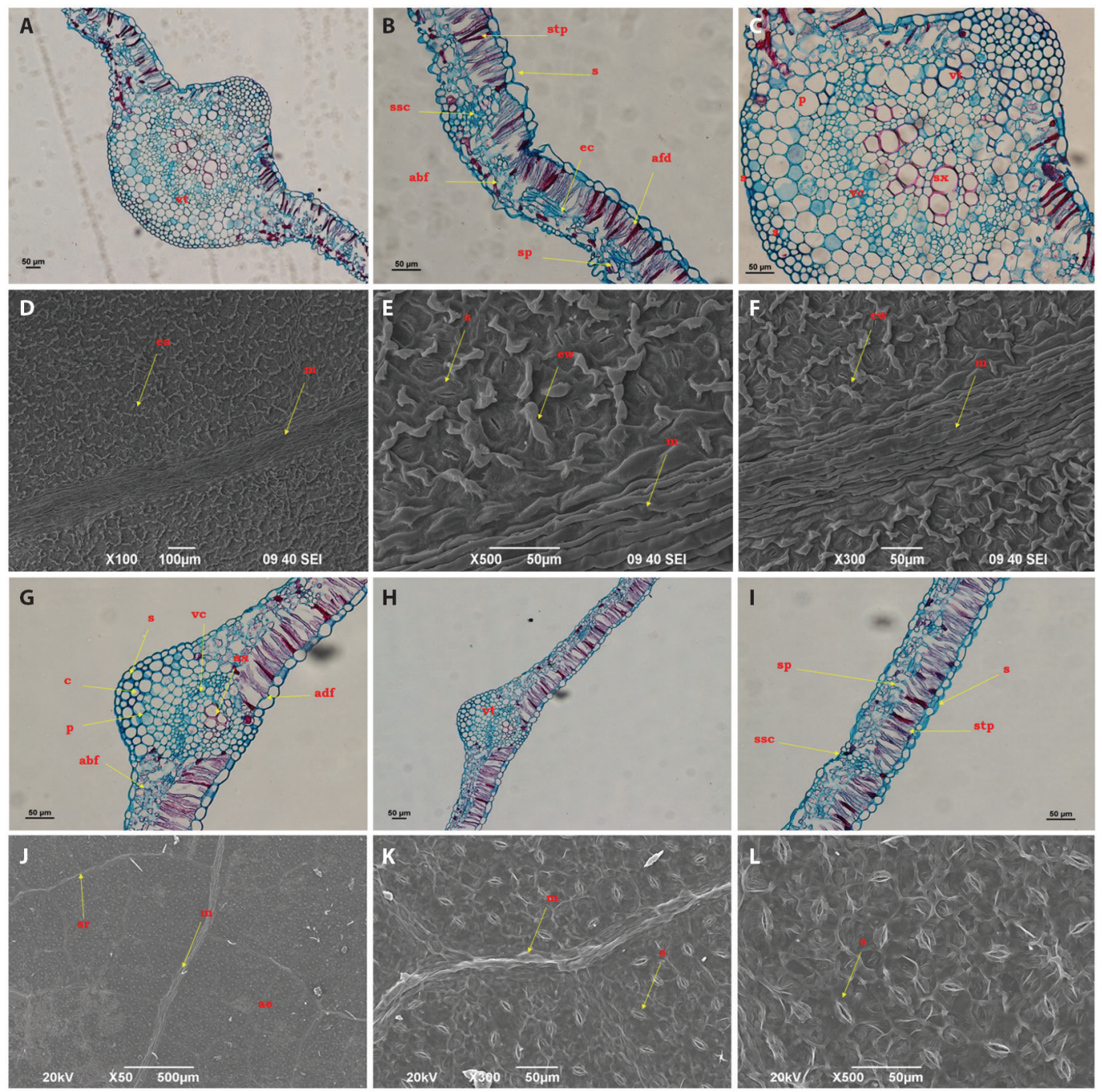

Fig. 1. MF-CDI and MEB analysis of the foliar lamina and a general view of transversal sections of cassava materials (Manihot esculenta): A-F. ALT6, G-L, ALT12. The presence of polyphenols, epicuticle waxes and papilla is observed. ae: adaxial epidermis; stp: stake parenchyma; sp: spongy parenchyma; cs: cellular strata; ssc: sub-stoma chambers; adf: adaxial face; abf: abaxial face; rtc: rectangular cells; rc: rounded cells; pc: papillary cells; tr: trichoma; m: midrib; sr: secondary rib; s: stoma; ec: epidermis cells; oc: occlusive cells; toc: turgid occlusive cells; ew: epicuticular waxes; xr: xylem ribs; pc: phloem caps; ca: collenchyma abaxial; vt: vascular tissue; sx: secondary xylem; vc: vascular cambium; p: phloem; c: cortex.

vanilla and ferric chloride were used to identify the phenolic compounds, but here it should be mentioned that there was a positive reaction in cells of the fundamental and spongy parenchyma. These same cells were intensely stained width safranin and these compounds were especially abundant in varieties NAT31
(Fig. 3A, 3B, 3C) and ECU72 (Fig. 3G, 3H, 3I, Table 2). The genotypes that often have polyphenols on the palisade and spongy parenchyma are: ALT6 (Fig. 1A, 1B), ALT12 (Fig. 1G, 1H, 1I) and PER182 (Fig. 2A, 2B, Table 2). On the other hand, the genotypes with little or no polyphenol compounds were: CMC40 (Fig. 


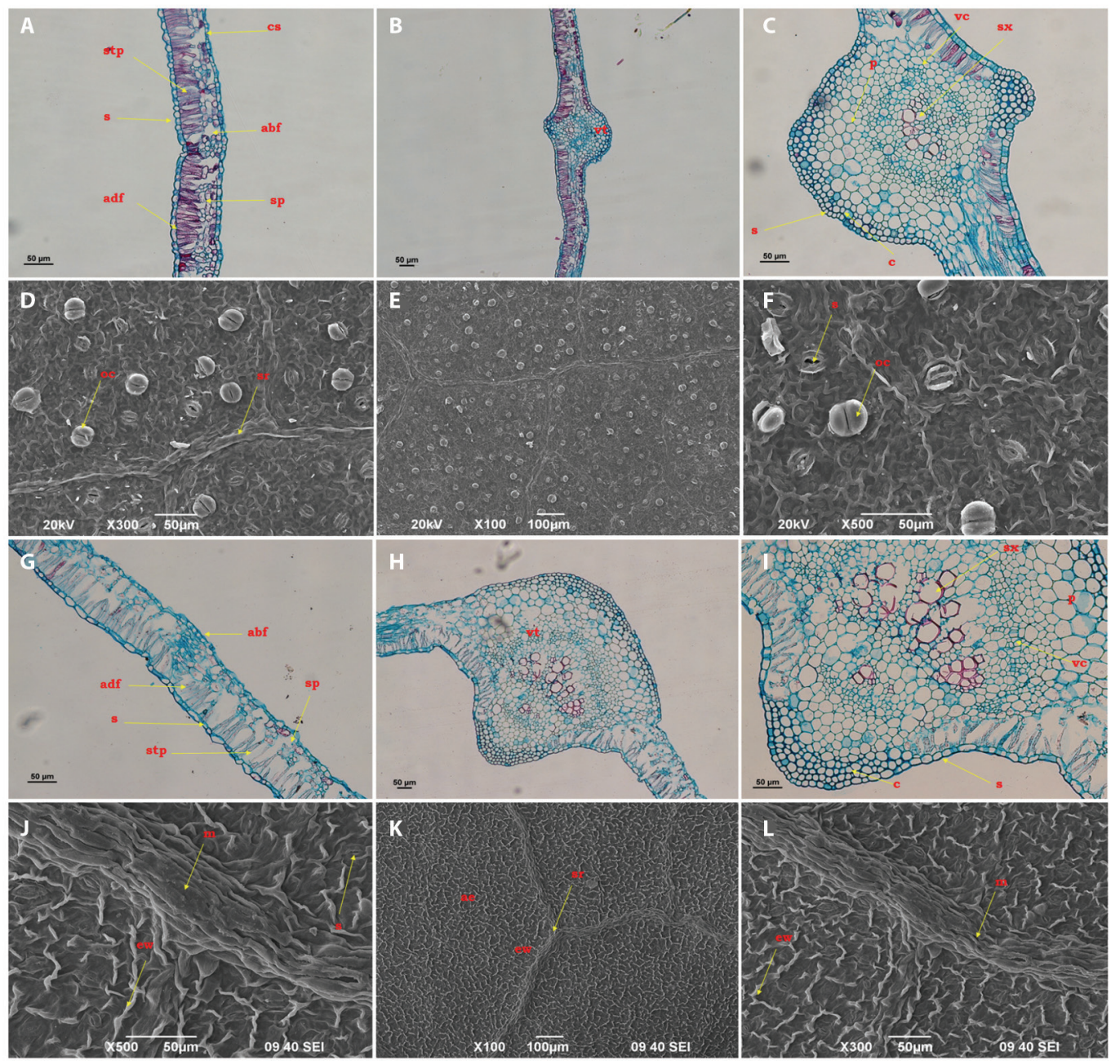

Fig. 2. MF-CDI and MEB analysis of the foliar lamina and a general view of transversal sections of cassava materials (Manihot esculenta): A-F. PER182; G-L, CMC40. The presence of polyphenols, epiculticular waxes and papilla is observed. ae: adaxial epidermis; stp: stake parenchyma; sp: spongy parenchyma; cs: cellular strata; ssc: sub-stoma chambers; adf: adaxial face; abf: abaxial face; rtc: rectangular cells; rc: rounded cells; pc: papillary cells; tr: trichoma; m: midrib; sr: secondary rib; s: stoma; ec: epidermis cells; oc: occlusive cells; toc: turgid occlusive cells; ew: epicuticular waxes; xr: xylem ribs; pc: phloem caps; ca: collenchyma abaxial; vt: vascular tissue; sx: secondary xylem; vc: vascular cambium; p: phloem; c: cortex.

2G, 2H), ECU160 (Fig. 4A, 4B), 60444 (Fig. 4G, 4H), PER335 (Fig. 5A, 5B), PER415 (Fig. $5 \mathrm{G}, 5 \mathrm{H}$, Table 2).

Trichomes: Trichomes are only present on the abaxial surface of the NAT31 (Fig. 3D, 3E, 3F) and ECU72 (Fig. 3J, 3K, 3L) varieties but they are generally restricted to the midrib on the first and secondary vascular bundle; in the NAT31 variety, they are distributed throughout the abaxial surface of the leaflet of NAT31 (Fig. 3D, 3E) and ECU72 (Fig. 3J, 3L). In both varieties, the trichomes are unicellular with a sharp apex (Fig. 3E, 3K, Table 2). 

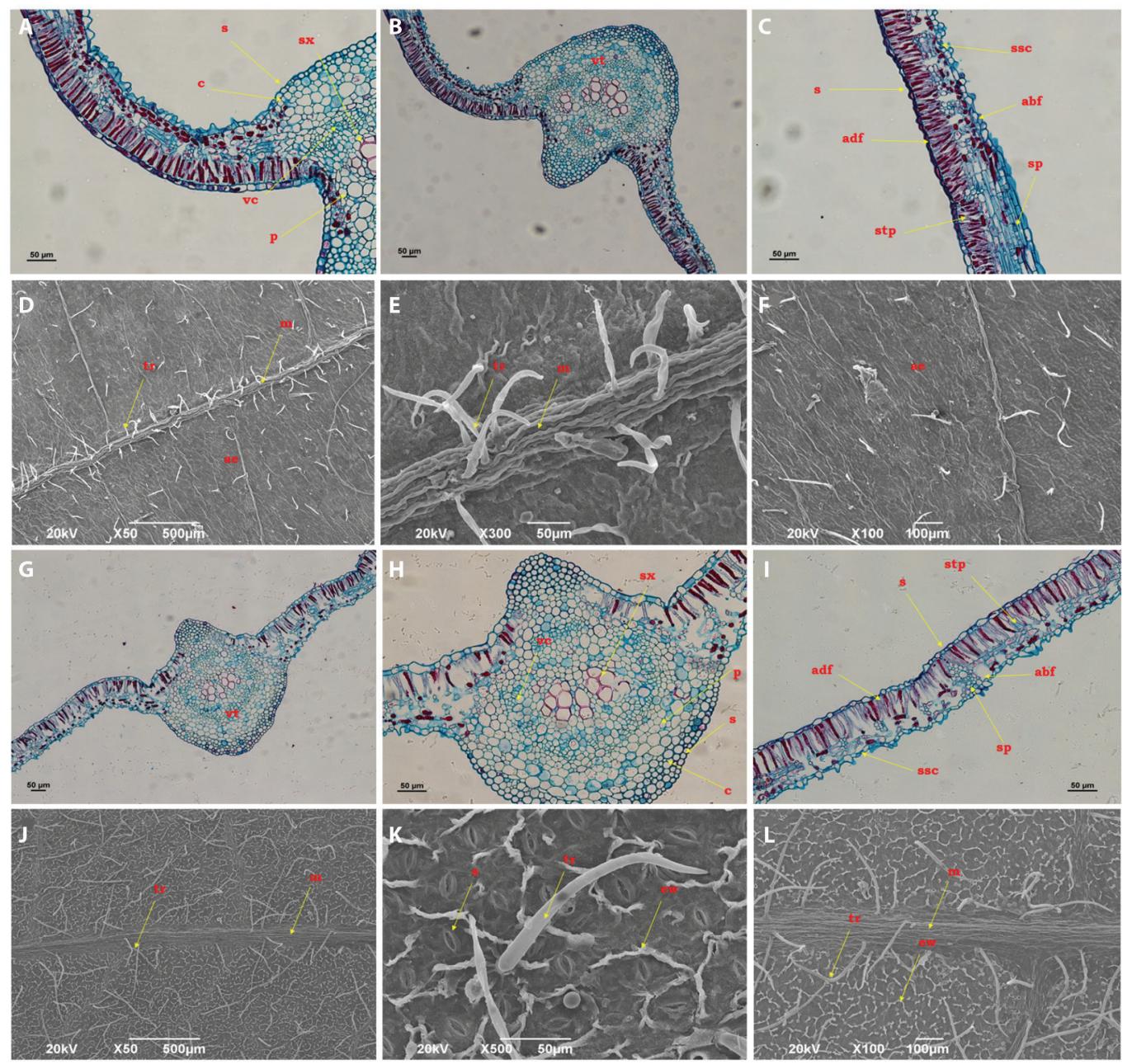

Fig. 3. MF-CDI and MEB analysis of the foliar lamina and a general view of transversal sections of material: A-F. NAT31; G-L. ECU72. The presence of polyphenols, epiculticular waxes and papilla is observed. ae: adaxial epidermis; stp: stake parenchyma; sp: spongy parenchyma; cs: cellular strata; ssc: sub-stoma chambers; adf: adaxial face; abf: abaxial face; rtc: rectangular cells; rc: rounded cells; pc: papillary cells; tr: trichome; m: midrib; sr: secondary rib; s: stoma; ec: epidermis cells; oc: occlusive cells; toc: turgid occlusive cells; ew: epicuticular waxes; xr: xylem ribs; pc: phloem caps; ca: collenchyma abaxial; vt: vascular tissue; sx: secondary xylem; vc: vascular cambium; p: phloem; c: cortex.

\section{DISCUSSION}

There are few studies about cassava comparing varieties at anatomical level in order to establish differences and possible relationships with resistance or tolerance characteristics to biotic and/o abiotic stresses (Nukenine et al., 2002; Bellotti, 2008; Ribeiro, Carvalho, Pereira, \& Castro, 2012; Mutisya et al., 2013;
Da Cunha Neto et al., 2014; Parsa, Medina, \& Rodríguez, 2015). Da Cunha Neto et al., (2014) described the anatomy of the leaves of wild species of Manihot and identified important taxonomic characteristics. For this purpose, samples of Manihot violacea var. cecropiifolia, Manihot violacea var. divergens, Manihot violacea subsp. jacobinensis (Lencois) were used but $M$. esculenta did not. 

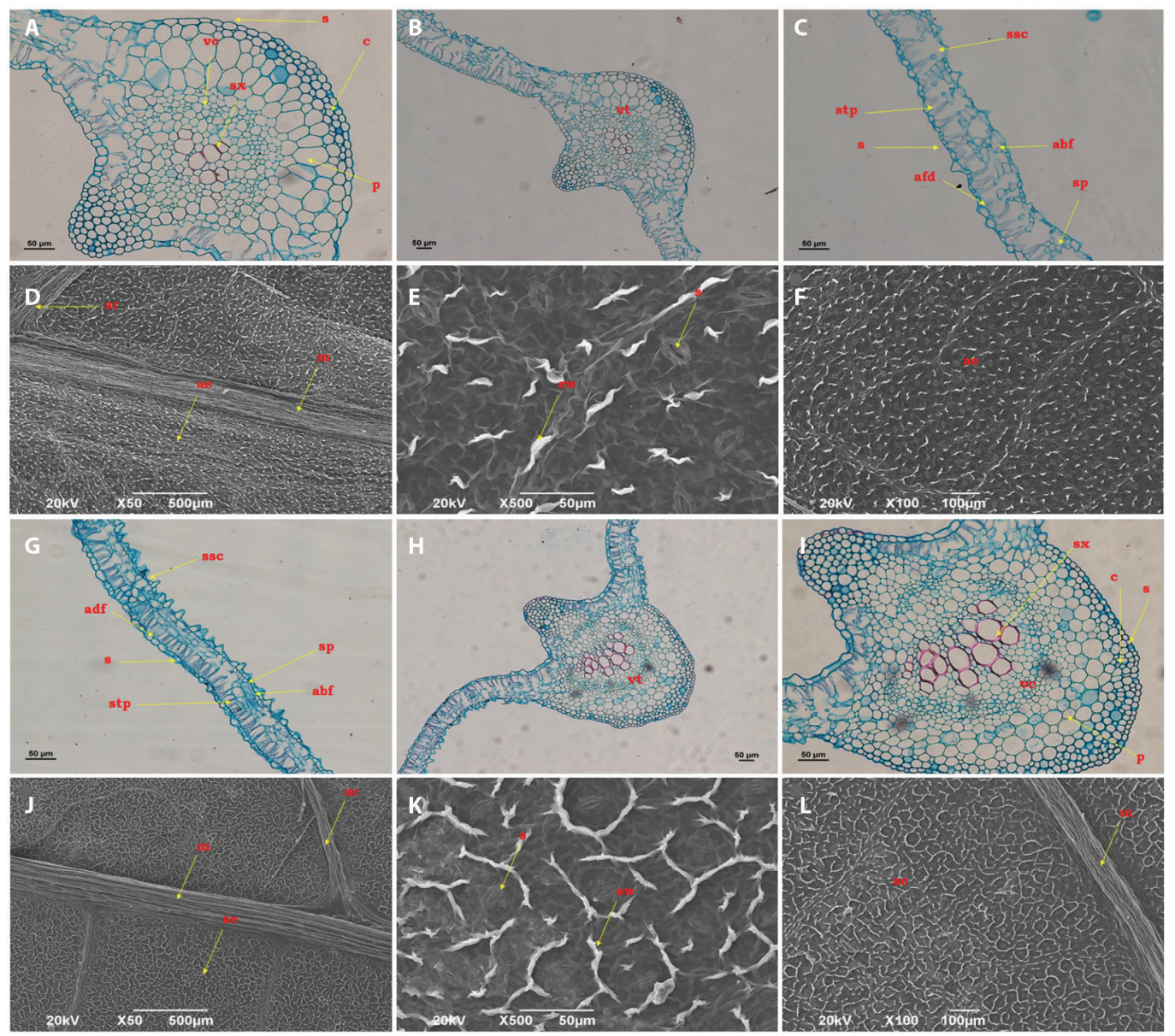

Fig. 4. MF-CDI and MEB analysis of the foliar lamina and a general view of transversal sections of materials: A-F. ECU160; G-L. 60444. The presence of polyphenols, epiculticular waxes and papilla is observed. ae: adaxial epidermis; stp: stake parenchyma; sp: spongy parenchyma; cs: cellular strata; ssc: sub-stoma chambers; adf: adaxial face; abf: abaxial face; rtc: rectangular cells; rc: rounded cells; pc: papillary cells; tr: trichome; m: midrib; sr: secondary rib; s: stoma; ec: epidermis cells; oc: occlusive cells; toc: turgid occlusive cells; ew: epiculticular waxes; xr: xylem ribs; pc: phloem caps; ca: collenchyma abaxial; vt: vascular tissue; sx: secondary xylem; vc: vascular cambium; p: phloem; c: cortex.

In all the varieties analyzed, the presence of an adaxial and abaxial epidermis is observed, generally cells with a rounded contour, although in the NAT31 varieties the cells of the adaxial and abaxial face are of papillary contour, these observations are similar to those recorded by other authors in $M$. esculenta leaves. The cut is parenchymatic with rounded-shape cells in the external region, with 4-5 layers of collenchymatic cells forming a ring in the sub-epidermal region. In all the accessions, collenchymatic cells are found immediately under the epidermis. The findings of our research were very similar to those reported by Da Cunha Neto et al. (2014). For example, in all the species studied, the epidermis is mono-stratified and cuticularized, and consists of rounded and rectangularshaped cells. Manihot violacea jacobinensis has papilliform cells on the abaxial surface and rounded and rectangular cells on the adaxial surface. Manihot violacea var. cecropiifolia and Manihot violacea var. divergens have nonglandular trichome whereas the other species 


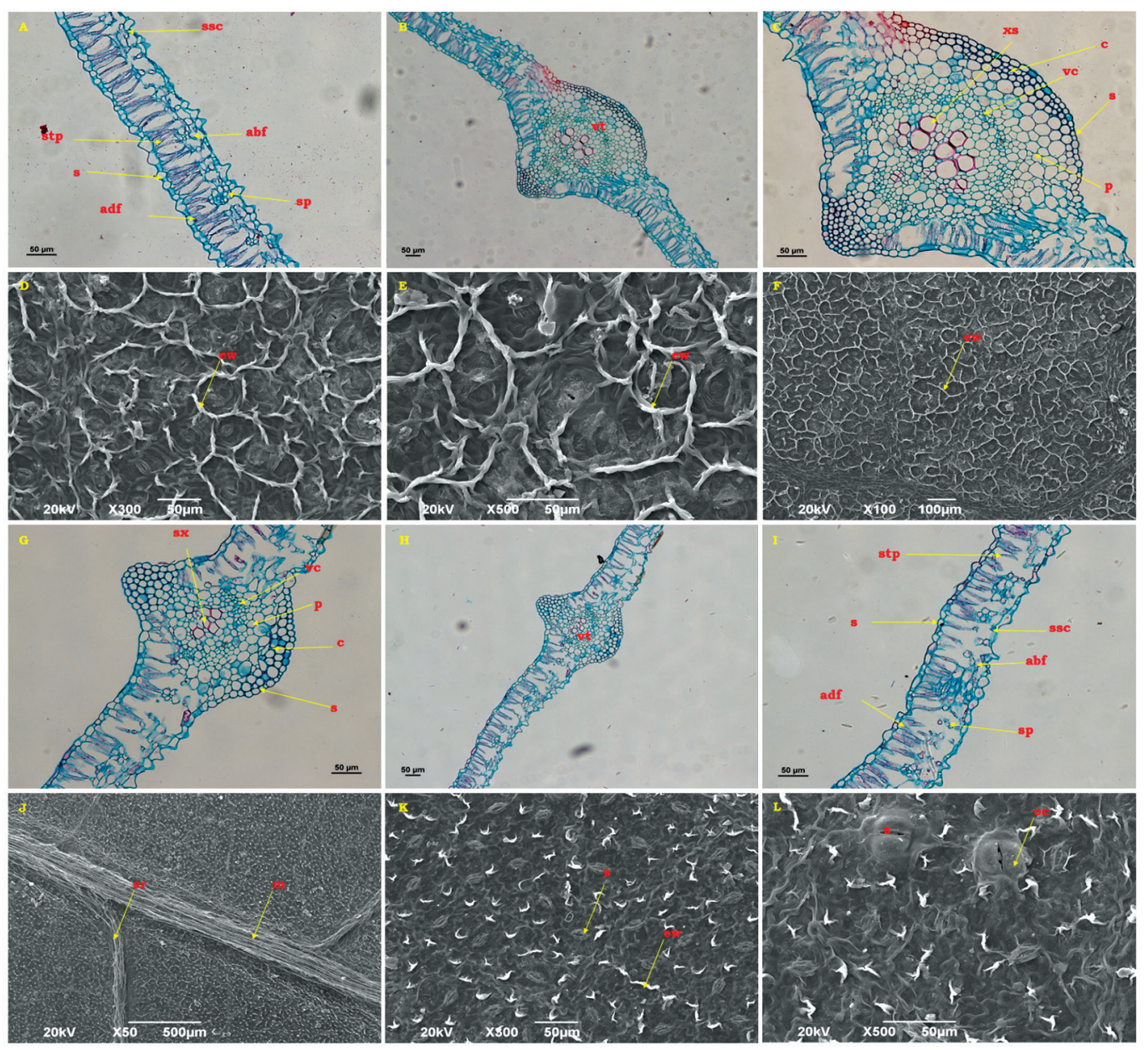

Fig. 5. MF-CDI and MEB analysis of the foliar lamina and a general view of transversal sections of materials: A-F. PER335; G-L. PER415. The presence of epiculticular waxes, papilla and turgid occlusive cells is observed: ae: adaxial epidermis; stp: stake parenchyma; sp: spongy parenchyma; cs: cellular strata; ssc: sub-stoma chambers; adf: adaxial face; abf: abaxial face; rtc: rectangular cells; rc: rounded cells; pc: papillary cells; tr: trichome; m: midrib; sr: secondary rib; s: stoma; ec: epidermis cells; oc: occlusive cells; toc: turgid occlusive cells; ew: epiculticular waxes; xr: xylem ribs; pc: phloem caps; ca: collenchyma abaxial; vt: vascular tissue; sx: secondary xylem; vc: vascular cambium; p: phloem; c: cortex.

have glandular trichome (Da Cunha Neto et al., 2014). A relevant factor in our study is the same way of Manihot violacea jacobinensis, NAT31 and ECU72 present the abaxial epidermal papillary cells. Further, they present trichomes (non-glandular) as $M$. violacea cecropiifolia and $M$. violacea var. divergens. The later might be considered as a differential factor from the rest of varieties evaluated. This might be related to the resistance to the green mites.
Our findings agree with these previous results in that the leaves are hipostomatic, as in M. violacea var. cecropiifolia and M. violacea var. divergens, In addition, the findings of the stomatal pattern type and the presence of these only on the abaxial side of the leaf lamina, is a conserved characteristic within the Manihot species (Da Cunha Neto et al., 2014). Ribeiro et al., (2012) found high anatomical plasticity of thirteen cassava genotypes in order to 
assure their potential for adapting to different environmental conditions and on analyzing quantitative changes in internal structures. This allowed to infer some adaptations to xerophytic conditions due to the high density of the stomata; thick adaxial epidermis; thick/palisade, spongy parenchyma; low vulnerability of the xylem; and great thickening of the phloem that might reduce the transpiration and use of the incidence of radiation (Castro, Pereira, \& Paiva, 2009; Batista, Guimaraes, Pereira, Calvalho, \& Mauro de Castro, 2010; Souza et al., 2010). For our case, the great majority of genotypes present this characteristic. Ribeiro et al., (2012) evaluated the following five characteristics of foliar tissues in transversal sections of cassava genotypes: TEAF $=$ thickness of epidermal adaxial face, TPP $=$ thickness of palisade parenchyma, TSP = thickness of spongy parenchyma, CVI = Carlquist vulnerability index, TP $=$ thickness of phloem. These authors found that the high values for PP and PS might be directly correlated with photosynthesis and sclerophyllia which, in their turn, might be adapted to higher radiation and water difference conditions in the genotypes UFLA E, IAC 14 and UFLA J, associated with stomatic characteristics, related with reduce of transpiration and to avoid incident filing. The characteristics evaluated by Nukenine et al., (2000) and Ribeiro et al., (2012) are like those found in our varieties, which confirms that the high anatomical plasticity of the plants. These three studies should corroborate the great plasticity of the cassava genotypes that can be useful as a potential factor for the selection of desirable characteristics for different environmental conditions, such as a resistance to pest's attacks.

Under microscopic observation of transversal sections of cassava leaves, Nukenine et al., (2000) found that the distribution of tissue was similar on the midrib and lamina in the five genotypes. Typical tissue distribution, from the adaxial and abaxial part of the midrib, consisted of some thick wall some tick on epidermis cells, some equally thick wall on sclerenchyma cells, xylem, phloem, many cells thick parenchyma, few to many cells thick sclerenchyma, and one cell thick lower epidermis. On comparing our research with these results, the same homogeneous distribution, structure and organization on the leaflet blade of the varieties studied were found.

In general terms, it can be concluded that idioblasts with polyphenols are found in cells of the palisade and spongy parenchyma of all varieties and they are stratified between the palisade and spongy parenchyma. In our study, some varieties show a greater number of these idioblasts than others, for example, the varieties NAT31 and ECU72 show a greater number of idioblasts with polyphenols when compared to the other varieties. There are several works that relate the presence of polyphenols with resistance to herbivores and here in this part it could be indicated that these polyphenols perhaps discourage herbivores in this case mites, however, I do not know if this higher concentration of polyphenols in some varieties that in others coincide with the registered on resistance for these varieties. There is a relationship between the amount of idioblasts with polyphenols and the resistance of these two varieties (NAT31-ECU72) to mites (Lattanzio, Lattanzio, \& Cardinali, 2006; Aoun, Rioux, Simard, \& Bernier, 2009; Aoun, 2017). The NAT 31 variety, considered resistant to the green mite and the white fly, shows a high correlation to the presence of the aforementioned characteristics, while ECU72, considered resistant to the whitefly (Bellotti, Herrera, \& Hyman, 2012), has trichomes (no glandular) and polyphenols. Other varieties such as ALT6, ALT12, PER182 only have polyphenols on the idioblasts. Probably, during domestication of cassava, some materials have lost certain typical morphological characteristics of a wild ancestor (Mondolot et al., 2008).

Several works shown the correlation between the high density of trichomes and resistence to $M$. tanajoa. For instance, Hahn, Isoba, \& Ikotun, (1989) and Kanno, Dixon, Asiedu, \& Hahn, (1992) found a significant and positive correlation among the cassava genotypes, leaf trichome density and the resistance to M. tanajoa. Another important aspect to be 
regarded are leaves which represent a physical factor involved in cassava resistance to $M$. tanajoa. Differences in anatomical structure of leaves between susceptible and resistant host plants are regarded as one of the most important factors determining mite feeding (Peters \& Berry, 1980).

The reduced $M$. tanajoa density at the top of resistant genotypes compared with susceptible genotypes may be due to lower suitability of the leaves of the resistant genotypes, this would be happening in the NAT31 and ECU72 varieties. In addition to the lower nutrient quality of these leaves, dense and long foliar trichomes may account for their lower suitability to M. tanajoa (Hahn et al., 1989; Kanno et al., 1992). Differences in anatomical parameters of plant parts between susceptible and resistant genotypes have been shown to contribute to resistance to insects. Variations in anatomical structure of leaves between susceptible and resistant host plants were regarded as one of the most important factors in determining mite feeding (Peters and Berry, 1980).

Kanno et al. (1992) found only non-glandular trichomes on several cassava cultivars and concluded that trichomes may act as a mechanical disturbance to the feeding behaviour of M. tanajoa, this characteristic is the one shown by the NAT31 and ECU72 varieties in our study. Higher pubescence intensity may in fact be partially responsible for the comparatively little damage by $M$. tanajoa on pubescent cultivars, in our case, the NAT 31 variety would show this characteristic. The denser the trichomes, the more movement of $M$. tanajoa will be impeded, leading to reduced feeding. This ability of highly pubescent cultivars to conserve mites during the rainy season might be useful in the classical biological control of $M$. tanajoa. Mite densities are usually very low during the rainy season (Akinlosotu, 1982; Yaninek et al., 1988), providing little food for phytoseiid predators that have been released for the classical biological control of $M$. tanajoa in Africa (Yaninek et al., 1988). Therefore, high pubescence intensity may help to conserve prey for these phytoseiids during the rainy season, but the influence of pubescence on phytoseiid efficiency and survival on the cassava plant needs to be investigated.

According to Nukenine et al., 2002, two cultivars (30474 and 4(2)1425P) with shorter and a lower percentage of erect trichomes endured higher mite damage than the two cultivars (91934 and TME 1), with longer and a higher percentage of erect trichomes. Regardless of season, length and orientation of the trichome may be involved in the varietal resistance of cassava to $M$. tanajoa. Our results, NAT31 and ECU72 presented non glandular trichomes, which according to the literature are linked to the resistance to $M$. tanajoa. In other study, Bohórquez, (2009) suggests that NAT31 has antibiosis and antixenosis characteristics against the whitefly $A$. socialis. Burbano et al. (2007), when evaluated wild Manihot species found natural resistance to Mononychellus tanajoa (Acariformes), Aleurotrachelus socialis and Phenacoccus herreni (Hemiptera). Vargas, Rey, Arias, and Bellotti, (2002) reported for the first time the benefits of NAT31, as resistant $M$. esculenta variety to the whitefly A. socialis. NAT31 has a high trichomes density on its leaves. These have been involved in the defense against herbivores, since they are extremely variable in form and structure (Johnson, 1975). Further, their anti-herbivory function has been widely documented (Levin, 1973; Agren \& Schemske, 1993; Løe, Toräng, Gaudeul, \& Agren, 2007; Mauricio \& Rausher, 1997). In addition, the trichomes have an ecophysiological role, because they reduce the exposure of the leaf to the UV rays and the water loss (Ehleringer, Björkman, \& Mooney, 1976). All of these, in turn, induce damage in the development and behavior of the herbivore pests (Agrawal et al., 2009).

In evolutionary perspective, pests are considered are identified as one of the key factors for species selection. They have shaping populations as they exert pressure on them, favoring certain genetic traits. Green mite has exerted enormous selection pressure on cassava. In this evolutive interaction the plant has developed defense mechanisms to counteract 
that negative pressure. Defense strategies vary from affecting the mite's preferences for the plant or, its reproductive fitness over the host plant or indirectly, attracting natural enemies (Kessler \& Baldwin, 2001; Dicke, Van Loon, \& Soler, 2009).

Constitutive and induced defenses are part of the arsenal defense of the plants to counteract the pests. Accession NAT31 exhibits constitutive defenses such as waxes, trichomes and secondary metabolites (Shepherd, Bass, Houtz, \& Wagner, 2005) while 60444 has secondary metabolites, only. Prior to the attack a reinforcement of the pre-existing defense and the setting up of new defenses might be occur. For instance, when the mite oviposits (Hilker \& Meiners, 2010) or emits pheromones (Fatouros, Dicke, Mumm, Meiners, \& Hilker, 2008) or walks on the underside of the leaves (Peiffer \& Felton, 2009) may generate direct or indirect changes on the cassava inductors. Plant direct defenses are those that affect the efficiency of the herbivore while indirect defenses are those that demand an intermediate actor (e.g. attraction of natural enemies by production of volatile compounds).

According to the results found, the differences between cassava genotypes can be summarized at this manner: difference in presence or non-presence of trichomes papilliform cells, epicuticular wax cells, and difference in polyphenolic compounds. This would lead us to speculate our hypothesis, which is based on the possible relationship of the resistance of cassava to attack by pests through constitutive resistance (presence of trichomes, epicuticular waxes, special disposition on the epidermis and presence of polyphenolic compounds). The results of the anatomic study of the foliar lamina allowed the identification of clear differences between the ten cassava genotypes regarding the following characteristics: trichomes, papilliform cells, epicuticle cells, cells wall and disposition of the midrib as well as its height and width; also the number of parenchyma layers present the abaxial collenchyma and vascular tissue, and the differences of the polyphenolic contents. The NAT31 material showed differences in the presence of trichomes, epicuticular waxes, and polyphenol in comparison with the other varieties.

Ethical statement: author contributions: J.M., E.R and J.M.L. designed research. J.M. performed research. J.M and E.R. analyzed the data. J.M., E.R and J.M.L wrote the article. Authors declare that they all agree with this publication and made significant contributions; that there is no conflict of interest of any kind; and that we followed all pertinent ethical and legal procedures and requirements. All financial sources are fully and clearly stated in the acknowledgements section. A signed document has been filed in the journal archives.

\section{ACKNOWLEDGMENTS}

Authors thank to Adriana Alzate and Mario Salazar for their technical support. The funds provided by Colciencias and Univalle throughout grants 1106-521-28281: "Molecular characterization of resistance in cassava (Manihot esculenta Crantz) to attack the green mite (Mononychellus tanojoa): a proteomics approach" and the PhD grant awarded by Colciencias to the student Jaime Marín 4942009.

\section{RESUMEN}

Anatomía foliar de diez genotipos de la planta Manihot esculenta (Euphorbiaceae). Introducción: La yuca Manihot esculenta (Crantz) es un arbusto perenne nativo de América del Sur que es una fuente esencial de carbohidratos para más de 600 millones de personas en países tropicales. Objetivo: El objetivo de este estudio fue describir y comparar la anatomía de la lámina de la hoja de diez genotipos de yuca. Métodos: se procesó la metodología para las descripciones anatómicas y se incluyeron 30 hojas de cada una de las variedades y se seccionaron de acuerdo con los protocolos de impregnación de parafina. Resultados: Los resultados mostraron que la estructura anatómica de la lámina de la hoja de todas las variedades en términos generales muestra diferencias. Todas las variedades tenían epidermis monostratificada, el mesófilo foliar consistía en un parénquima empalizado en una sola capa y múltiples capas de parénquima esponjoso. Se observaron idioblastos polifenólicos sumergidos en el parénquima empalizada y el parénquima esponjoso. Se encontraron entre 3-7 costillas de xilema con su respectivo floema en 
el nervio central en casi todas las variedades. Los tricomas solo se encontraron en dos variedades (NAT31-ECU72) y las hojas eran todas hipostomáticas. Conclusiones: Los resultados revelan que NAT31 es el material con las diferencias más marcadas anatómicamente (es decir, presencia de tricomas, células papilares y, en la cara adaxial, disposición especial de los patrones de estomas y cera epicutícula), características que podrían estar relacionadas con la resistencia a las plagas.

Palabras clave: yuca; idioblastos; mesófilo; polifenoles; tricomas.

\section{REFERENCES}

Agrawal, A.A., Fishbein, M., Jetter, R., Salminen, J.P., Goldstein, J.B., Freitag, A.E., \& Sparks, J.P. (2009). Phylogenetic ecology of leaf surface traits in the milkweeds (Asclepias spp.): chemistry, ecophysiology, and insect behavior. New Phytologist, 183, 848-867.

Agren, J., \& Schemske, D.W. (1993). The cost of defense against herbivores: an experimental study of trichome production in Brassica rapa. American Naturalist, $141,338-350$.

Akinlosotu, T.A. (1982). Seasonal trend of green spider mite, Mononychellus tanajoa population on cassava, Manihot esculenta and its relationship with weather factors at Moor Plantation. Insect Science and its Application, 3, 251-254.

Aoun, M. (2017). Host defense mechanisms during fungal pathogenesis and how these are overcome in susceptible plants: A review. International Journal of Botany, $13,82-102$

Aoun, M., Rioux, D., Simard, M., \& Bernier, L. (2009). Fungal colonization and host defense reactions in Ulmus americana callus cultures inoculated with Ophiostoma novo-ulmi. Phytopathology, 99, 642-650.

Batista, L.A., Guimaraes, R.J., Pereira, F.J., Carvalho, G.R., \& Mauro de Castro, E. (2010). Anatomia foliar e potencial hídrico na tolerância de cultivares de café ao estresse hídrico. Revista Ciência Agronômica, $41(3), 475-481$.

Bellotti, A.C. \& Arias, B. (2001). Host plant resistance to whiteflies with emphasis on cassava as a case study. Crop Protection, 20, 813-823.

Bellotti, A., Arias, B., Vargas, V., Reyes, H., \& Guerrero, J. (2002). Insectos y ácaros dañinos a la yuca y su control. In B. Ospina \& H. Ceballos (Eds.), La yuca en el tercer milenio. Sistemas modernos de producción, procesamiento, utilización y comercialización (pp. 160-203). Colombia: CIAT Publicación.
Bellotti, A. (2008). Cassava pest and their management. In J.L. Capinera (Ed.), Encyclopedia of Entomology (pp. 764-794). Germany: Springer

Bellotti, A.C., Herrera, B.V., \& Hyman, G. (2012). Cassava production and pest management: present and potential threats in a changing environment. Tropical Plant Biology, 5, 39-72.

Bohórquez, A. (2009). Aislamiento de secuencias expresadas diferencialmente durante la respuesta de defensa al ataque de la mosca blanca (Aleurotrachelus socialis) en el cultivo de yuca (Manihot esculenta Crantz) mediante genómica funcional (Doctoral dissertation). Universidad Nacional de Colombia, Colombia.

Burbano, M., Carabalí, A., Montoya-Lerma, J., \& Bellotti, A. (2007). Resistencia natural de especies silvestres de Manihot (Euphorbiaceae) a Mononychellus tanajoa (Acariformes), Aleurotrachelus socialis y Phenacoccus herreni (Hemiptera). Revista Colombiana de Entomología, 33(2), 110-115.

Buravkov, S.V., Chernikov, V.P., \& Buravkova, L.B. (2011). Simple method of specimen preparation for scanning electron microscopy. Bulletin of Experimental Biology and Medicine, 151, 378-382.

Castro, E.M., Pereira, F.J., \& Paiva, R. (2009). Histologia Vegetal: estrutura e função dos órgãos vegetativos. Lavras, Brazil: Universidade Federal de Lavras.

Da Cunha Neto, I.L., Martins, F., Caiafa, A., \& Martins, M. (2014). Leaf anatomy as subsidy to the taxonomy of wild Manihot species in Quinquelobae section (Euphorbiaceae). Brazilian Journal of Botany, 37, 481-484. DOI: 10.1007/s40415-014-0057-2

Dicke, M., Van Loon, J., \& Soler, R. (2009). Chemical complexity of volatiles from plants induced by multiple attack. National Chemical Biology, 5, 317-324.

Ehleringer, J., Björkman, O., \& Mooney, H.A. (1976). Leaf pubescence-effects on absorbance and photosynthesis in a desert shrub. Science, 192, 376-377.

El-Sharkawy, M.A., Cock, J.H., \& Porto, M.C.M. (1989). Caracteristicas fotosinteticas da mandioca (Manihot esculenta Crantz). Revista Brasilera de Fisiología Vegetal, 01(2), 143-154.

FAO. (2012). Food outlook. Global market analysis - November 2012. Rome, Italy: FAO.

Fatouros, N.E., Dicke, M., Mumm, R., Meiners, T., \& Hilker, M. (2008). Foraging behavior of egg parasitoids exploiting chemical information. Behavior Ecology, 19(3), 677-689.

Fauquet, C., \& Fargette, D. (1990). African cassava mosaic virus. Etiology, epidemiology and control. Plant Disease, 74, 404-411. 
Hahn, S.K., Isoba, J.C.G \& Ikotun, T. (1989). Resistance breeding in root and tuber crops at the International Institute of Tropical Agriculture, Ibadan, Nigeria. Crop Protection, 8, 147-168.

Hilker, M., \& Meiners T. (2010). How do plants "notice" attack by herbivorous arthropods? Biological Reviews, 85, 267-280.

Johnson, B. (1975). Plant pubescence. An ecological perspective. Botanical Review, 41, 233-258.

Kanno, H., Dixon, A.G.O., Asiedu, R., \& Hahn, S.K. (1992). Breeding for host plant resistance to cassava green spider mide (CGM) at IITA. In M.N. Alvarez, $\&$ R. Asiedu (Eds.), The role of root and tuber crops in regional food security and sustainable agricultura Proceeding of the fourth Eastern and Southern Africa regional workshop on root and tuber crops, 29 Oct-2 Nov, 1990 (2nd ed., pp. 99-102). Zambia: International Institute of Tropical Agriculture.

Kessler, A., \& Baldwin, I.T. (2001). Defensive function of herbivore-induced plant volatile emissions in nature. Science, 291, 2141-2144.

Klamkowski, K., Sekrecka, M., Fonyodi, H., \& Treder, W. (2006). Changes in the rate of gas exchange, water consumption and growth in strawberry plants infested with the two-spotted spider mite. Journal of Fruit and Ornamental Plant Disease, 14, 155-162.

Lattanzio, V., Lattanzio, M.T.V., \& Cardinali, A. (2006). Role of phenolics in the resistance mechanisms of plants against fungal pathogens and insects. In F. Imperato (Ed.), Phytochemistry: advances in research (pp. 23-67). India: Research Signpost.

Levin, D.A. (1973). The role of trichomes in plant defence. Quarterly Review of Biology, 48, 3-15.

Løe, G., Toräng, P., Gaudeul, M., \& Agren, J. (2007) Trichome production and spatiotemporal variation in herbivory in the perennial herb Arabidopsis lyrata. Oikos, 116, 134-142.

Mauricio, R., \& Rausher, M.D. (1997). Experimental manipulation of putative selective agents provides evidence for the role of natural enemies in the evolution of plant defense. Evolution, 51, 1435-1444.

Mondolot, L., Marlas, A., Barbeau, D., Gargadennec, A., Pujol, B., \& McKey, D. (2008). Domestication and defense: Foliar tannins and $\mathrm{C} / \mathrm{N}$ ratios in cassava and a close wild relative. Acta Oecologica, 34, 147-154.

Mutisya, D.L., El-Banhawy, E.M., Khamala, C.P.M., \& Kariuki, C.W. (2015). Management of cassava green mite Mononychellus progresivus (Acari: Tetranychidae) in different agro-ecological zones of Kenya. Systematic and Applied Acarology, 20(1), 39-50.

Nukenine, E.N., Hassan, A.T., \& Dixon, G.O. (2000). Influence of variety on the within-plant distribution of cassava green spider mite (Acari: Tetranychidae), and leaf anatomical characteristics and chemical components in relation to varietal resistance. International Journal of Pest Management, 46(3), 177-186.

Nukenine, E., Dixon, A., Hassan, A., \& Zalom, F. (2002). Relationships between leaf trichome characteristics and field resistance to cassava green mite, Mononychellus tanajoa (Bondar). Systematic Applied Acarology, 7, 77-90.

Parsa, S., Medina, C., \& Rodríguez, V. (2015). Sources of pest resistance in cassava. Crop Protection, 68, 79-84.

Peiffer, M., \& Felton, G.W. (2009). Do caterpillars secrete "oral secretions"? Journal of Chemical Ecology, 35, 326-335.

Peters, K.M., \& Berry, R.E. (1980). Effects of hop leaf morphology on two spotted spider mite. Journal Economic Entomology, 73, 235-238.

Ribeiro, M., Carvalho, S.P., Pereira, F.J., \& Castro, E.M. (2012). Leaf anatomy of the cassava as related to potential for tolerance to different environmental conditions. Revista de Ciencia Agronómica, 43(2), 354-361.

Riis, L., Bellotti, A.C., Bonierbale, M., \& O’Brien, G.M. (2003). Cyanogenic potential in cassava and its influence on a generalist insect herbivore Cyrtomenus bergi (Hemiptera:Cydnidae). Journal Economic Entomology, 96, 1905-1914.

Ruzin, S.E. (1999). Plant microtechnique and microscopy. New York, U.S.A.: Oxford University.

Shepherd, R.W., Bass, W.T., Houtz, R.L., \& Wagner, G.J. (2005). Phylloplanins of tobacco are defensive proteins deployed on aerial surfaces by short glandular trichomes. Plant Cell, 17, 2421-2421.

Souza, T.C., Magalhaes, P.C., Pereira, F.J., Mauro de Castro, E., Da Silva Junior, J.M., \& Parentoni, N. (2010). Leaf plasticity in sucessive selection cycles of 'Saracura' maize in response to soil flooding. Pesquisa Agropecuária Brasileira, 45(1), 16-24.

Vargas, H., Rey, B., Arias, V., \& Bellotti, A. (2002). Nataima-31: Variedad de yuca (Manihot esculenta Crantz) resistente a mosca blanca (Aleurotrachelus socialis Bondar) para el valle cálido del alto Magdalena. Bogotá, Colombia: Ministerio de Agricultura y Desarrollo Rural.

Yaninek, J.S., \& Herren, H.R. (1988). Introduction and spread of the cassava green mite, Mononychellus tanajoa (Bondar) (Acari: Tetranychidae), an exotic pest in Africa and the search for appropriate control methods: a review. Bulletin of the Entomological Research, 78(1), 1-13. 